\title{
Alkyl Polyglucoside-Based Emulsions as Vehicles for Topical Spironolactone: A Textural Analysis
}

\author{
Dušan Ilić, Maja Cvetković, Marija Tasić-Kostov \\ University of Niš, Faculty of Medicine, Department of Pharmacy, Niš, Serbia
}

SUMMARY

Acne vulgaris is a chronic dermatological disease that affects the pilosebaceous unit; androgens play an important role in its pathogenesis. Acne therapy can be either systemic or topical, usual in the treatment of mild and moderate forms of acne. Spironolactone (SP) is an anti-androgen drug with potential to reduce the sebum secretion; in order to avoid systemic side effects, it could be used topically in acne treatment. Nowadays, more and more attention is being paid to the textural profile of dermopharmaceutical emulsions, which is normally influenced by their colloidal structure; texture analysis is performed in order to predict behavior of the emulsion systems in real-time conditions during manufacturing and application; the latter is closely related to ensuring patients' compliance and the positive outcome of the therapy.

We formulated emulsions stabilized with different natural alkyl polyglucoside (APG) emulsifiers (Cetearyl glucoside and cetearyl alcohol and Arachidyl glucoside and arachidyl behenyl alcohol) as vehicles for $5 \%$ topical SP. Parameters obtained by texture analysis were firmness and cohesiveness. The study showed that SP affected the texture of APG-based emulsion; different APG-based emulsions showed satisfying textural characteristics per se after incorporation of $5 \%$ SP, which could imply their satisfying applicative characteristics on the skin with acne. APGs could be used as stabilizers of emulsion vehicles for topical SP. Dermoemulsion with Arachidyl glucoside and arachidyl behenyl alcohol, more lypophillic emulsifier, is a more acceptable carrier for $5 \%$ SP due to a better textural profile.

Key words: spironolactone, alkyl polyglucoside emulsifier, textural profile, off-label acne treatment

Corresponding author:

Marija Tasić-Kostov

e-mail: marijatk@medfak.ni.ac.rs 


\section{INTRODUCTION}

Acne vulgaris is a chronic dermatological disease that affects the pilosebaceous unit. It is characterized by increased sebum secretion, epithelial desquamation and inflammation, which usually occur on the face and neck (1). Acne has a major impact on the patient's quality of life, creating social and psychological problems $(2,3)$. Acne therapy can be either topical or systemic. Topicals are usually used to treat mild and moderate forms of acne, while they are combined with oral therapy in more severe forms (4). The principle of topical therapy is based on the influence on the pathogenetic factors of acne. The appropriate topical agent is chosen in accordance with the prevalent type of acne lesions (5), while the choice of a proper vehicle should be considered.

Spironolactone (SP) is an anti-androgen drug with potential to reduce the secretion from sebaceous glands, which can be crucial for acne therapy (6 - 9). In order to avoid systemic side effects, SP could be topically used $(8,9)$. In most cases, it is prescribed by dermatologist in a form of extemporaneous preparation with $5 \%$ of SP in a vehicle. The importance of a suitable topical vehicle is often neglected; amphiphilic pharmaceutical bases as "universal vehicles" are usually used in that purpose (10). However, there are no comprehensive studies which investigate the suitability of common pharmaceutical bases to serve as vehicles for topical SP in terms of acceptable applicative characteristics which are important in acne treatment and could affect patient adherence to therapy.

Recently, we investigated emulsions based on natural alkyl polyglucosides (APGs), a newer "green" FDA certified class of polyethylene glycolfree surfactants, as vehicles for topical SP. Emulsions with 5\% SP showed acceptable skin irritation profile and significant potential for skin hydration, also important in the acne treatment. Good physical stability was achieved, showing that APG-based emulsions could be introduced as safe and stable vehicles for topical SP with additional moisturizing benefits (9).

Texture analysis is a technique that was initially developed for studying the mechanical characteristics of food (11). Appropriate instruments record the behavior of the product under conditions that mimic those to which it is exposed during the production and use. The primary task of texture analysis is to consider the mechanical characteristics of a material exposed to a controlled force, whereby that material generates a deformation curve under certain conditions (12). The resulting graphs show the behavior of the force over time, representing the texture profile. The performance and quality (sensory and applicative characteristics) of cosmetics and dermopharmaceutics are tested using texture analysis (13); more and more attention is being paid to this kind of investigations of topical products. Texture of emulsions is influenced by their colloidal structure, so texture analysis could be performed in order to predict behavior of the emulsion in realtime conditions during manufacturing and application. Also, texture analysis is considered to be a method for assessing the stability of emulsions and, in addition to rheological measurements, it is of great importance in the process of formulation of the final pharmaceutical preparation (13 - 16).

It was reported that sensory and applicative characteristics of topicals are very important from the point of view of user acceptability (17). These features are closely related to ensuring patients' compliance; the outcome of the acne therapy largely depends on the regular use of topical medications throughout the therapy. Meeting consumer expectations, which are related to sensory and applicative characteristics of a topical product, became one of the pharmaceutical manufacturing imperatives. Researches related to human perception are attracting a lot of attention today (18). Special needs of skin with acne should be taken into consideration during the choice of the topical vehicle, with an emphasis on applicative characteristic of the preparation and moisturizing potential of a vehicle.

We formulated the emulsions stabilized with two different natural APG emulsifiers as vehicles for topical SP. The aim of this study was to investigate the texture profiles of APG-based emulsions per se and after incorporation of 5\% SP, in order to investigate if these emulsions could be used as vehicles for SP in topical acne therapy in terms of their applicative characteristics, and to compare their textural characteristics.

\section{MATERIALS AND METHODS}

\section{Formulation of the emulsions}

Based on the results of preliminary tests, ingredients were selected for the preparation of two 
samples of U/V creams with different (APG) emulsifiers. Those samples were marked as placebo samples F1 and F2. Active samples F3 and F4 contained $5 \%$ SP dispersed in the placebo emulsions (Table 1).
Samples were prepared by heating and stirring. For sample F1, the oily phase was heated to $70^{\circ} \mathrm{C}$ (magnetic stirrer IKAMAG (IKA, Germany)) with an emulsifier and then added under stirring

Table 1. Ingredients of tested samples

\begin{tabular}{|c|c|c|c|c|}
\hline \multirow{2}{*}{ Ingredient } & F1 & F2 & F3 & F4 \\
\hline & $(\% \mathrm{~m} / \mathrm{m})$ & $(\% \mathrm{~m} / \mathrm{m})$ & $(\% \mathrm{~m} / \mathrm{m})$ & $(\% \mathrm{~m} / \mathrm{m})$ \\
\hline Cetearyl glucoside \& cetearyl alcohol & 7 & & 7 & \\
\hline Arachidyl glucoside \& arachidyl behenyl alcohol & & 10 & & 10 \\
\hline Cetostearyl alcohol & 2 & 2 & 2 & 2 \\
\hline Caprylic/Capric Triglycerides & 10 & 10 & 10 & 10 \\
\hline Isopropyl myristate & 10 & & 10 & \\
\hline Cyclomethicone & & 10 & & 10 \\
\hline Glycerol & 2 & 2 & 2 & 2 \\
\hline Spironolactone & & & 5 & 5 \\
\hline Ethanol $96 \%$ & 5 & 5 & 5 & 5 \\
\hline Preservative & 0,5 & 0,5 & 0,5 & 0,5 \\
\hline Purified water & 63,5 & 60,5 & 58,5 & 55,5 \\
\hline
\end{tabular}

(800 rpm) to the aqueous phase containing glycerol, with temperature $2-5^{\circ} \mathrm{C}$ higher than the oily phase (propeller laboratory stirrer RV16 basic IKA ${ }^{\circledR V E R K E, ~}$ Germany). Stirring at constant temperature lasted for the next 5 minutes $(800 \mathrm{rpm})$ and then for additional 3 minutes (500 rpm). After the emulsification, cooling was started under stirring at $300 \mathrm{rpm}$ and ethanol and preservative were added to the emulsion (when temperature reached $40^{\circ} \mathrm{C}$ ). Stirring was continued until room temperature was reached. Sample F2 was prepared in the same manner, heating the oily phase to up to $80^{\circ} \mathrm{C}$, as recommended by the manufacturer (19). The aqueous phase was heated to $2-5^{\circ} \mathrm{C}$ higher temperature. Samples F3 and F4 were prepared in the same manner; additionally $5 \%$ of SP was dispersed in each vehicle immediately after its manufacturing.

\section{Texture profile analysis}

It was reported that textural parameters such as hardness, consistency, elasticity, cohesiveness and firmness reflect mechanical characteristics of semisolids relevant for their topical application (20 - 22).

Texture analysis of the emulsions was performed one week after preparation. A texture analyser (CT3, Brookfield engineering, USA) with $10 \mathrm{~kg}$ load cell was used. The samples were placed into the cone of spread test fixture and allowed to set at room temperature for $30 \mathrm{~min}$. Approximately, $75 \%$ of the container was filled with the sample, avoiding the introduction of air. The probe (TA15/1000) was programmed in compression mode to penetrate the sample to a depth of $16 \mathrm{~mm}$, at a pre-test speed 2 $\mathrm{mm} / \mathrm{s}$, test-speed of $1 \mathrm{~mm} / \mathrm{s}$ and at a return speed of $1 \mathrm{~mm} / \mathrm{s}$. The test was performed in two cycles. The data were collected and analyzed to determine firmness and cohesiveness, the most relevant parameters in objective assessment of applicative characteristics of topical emulsions.

\section{RESULTS}

Parameters obtained by texture analysis of samples investigated in this study are presented in Table 2. We have calculated the following parameters: firmness, as a parameter related to hardness (the maximum compression force required to attain a deformation), and cohesiveness (ratio of positive force area during the second compression to that during the first compression cycle of the sample), as a parameter related to adhesiveness. Sample F2 showed the highest, while sample F4 showed the lowest values for the both firmness and cohesiveness. 
Table 2. Textural parameters of tested samples

\begin{tabular}{c|c|c}
\hline \hline Sample & Firmness $(\mathrm{g})$ & Cohesiveness \\
\hline F1 & 154 & 0,95 \\
\hline F2 & 245 & 1 \\
\hline F3 & 203 & 0,75 \\
\hline F4 & 134 & 0,41 \\
\hline \hline
\end{tabular}

\section{DISCUSSION}

Firmness is the force that is necessary to achieve a certain deformation of semisolid topical preparation. Cohesiveness is the strength of internal bonds giving the structure to the semisolid product itself and it represents the limit to which a system can be deformed before it ruptures (23). Consistency is one of the important viscoelastic properties of emulsions that have influence on their acceptability and the organoleptic characteristics (24). The results (Table 2) indicate that both active and placebo samples have satisfactory values of both parameters, required for easy extrusion of preparation from the container, with application of low pressure, and for easy and pleasant application to the skin (21).

In samples with Cetearyl glucoside and cetearyl alcohol emulsifier (F1 and F3), the addition of SP led to an increase in the value of firmness and decrease in the value of cohesiveness, while among the samples with Arachidyl glucoside and arachidyl behenyl alcohol as emulsifier (F2 and F4) the addition of SP led to decrease in the both values of firmness and cohesiveness (Table 2).

Optimal textural adhesiveness is an ultimate characteristic of cosmetic creams, which must show elegancy during application and satisfying after-feel, which depends on adhesive properties of the topical. Taking the value for firmness between $188,3 \mathrm{~g}$ and $191,7 \mathrm{~g}$ and cohesiveness values between 0,79 and $0,96(25)$ as reference values for emulsions with satisfactory textural profile with very good spreading characteristics (20), the values obtained for investigated samples could indicate a satisfying adhesion characteristics, even comparable to cosmetics (Table 2 ) (20). According to this data, we can conclude that all samples showed satisfactory textural profiles. As the results show, the sample F3 required more force than the sample F1 (203 g, 154 g, respectively), show- ing that F3 is harder than F1. On the other hand, the addition of SP to the active sample F4 (134 g) led to a decrease in firmness value compared to the analogous placebo sample F2 (245 g). This showed that SP may affect the emulsion system differently, depending on the type of the emulsifier. The results of this study show that an emulsifier Arachidyl glucoside and arachidyl behenyl alcohol could be a better choice for the formulation of emulsions with $5 \%$ SP.

There is a correlation between the values of relevant texture profile parameters and the data obtained by the rheological measurements. Namely, high values of firmness and cohesiveness correspond to high hysteresis loop values, high viscosity and yield value, while low values of those parameters correspond to low values of relevant rheological parameters (20). It could be concluded that addition of $5 \%$ SP to emulsion with Cetearyl glucoside and cetearyl alcohol emulsifier leads to higher emulsion viscosity, while, on the other hand, addition 5\% SP to emulsion with Arachidyl glucoside and arachidyl behenyl alcohol emulsifier leads to slightly lower viscosity, without affecting the stability, indicating better spreading and after-feel characteristics of the preparation.

\section{CONCLUSION}

The results obtained in this study show that placebo and APG-based emulsions containing 5\% SP had satisfactory textural profiles. Both emulsifiers showed the potential to be used in stabilization of emulsion vehicles for dermocosmetic/dermopharmaceutics in terms of their textural characteristics and stability. The obtained results showed that addition of $5 \%$ SP could have some influence on the texture profile of investigated emulsion vehicles, which should be taken into account when formulating a final preparation, particularly in compounding practice. APG-based emulsions could be used as vehicles for topical SP showing satisfying ease of application to the skin and ease of extrusion from the container. Dermopharmaceutic emulsion stabilized with Arachidyl glucoside and arachidyl behenyl alcohol, a more lypophillic emulsifier, is more acceptable carrier for 5\% SP due to sligthly better textural profile, compared to emulsions stabilized with Cetearyl glucoside and cetearyl alcohol. 


\section{References}

1. Castro GA, Oliveira CA, Mahecha GA, Ferreira LA. Comedolytic effect and reduced skin irritation of a new formulation of all-trans retinoic acidloaded solid lipid nanoparticles for topical treatment of acne. Arch Dermatol Res 2011;303: 513-20. https://doi.org/10.1007/s00403-011-1130-3

2. Raza K, Singh B, Singla S, et al. Nanocolloidal carriers of isotretinoin: Antimicrobial activity against Propionibacterium acnes and dermatokinetic modeling. Mol Pharm 2013;10: 1958-63.

https://doi.org/10.1021/mp300722f

3. Ramos-e-Silva M, Ramos-e-Silva S, Carneiro S. Acne in women. Br J Dermatol 2015; 172(S1):20-6. https://doi.org/10.1111/bjd.13638

4. Tripathi SV, Gustafson CJ, Huang KE, Feldman SR. Side effects of common acne treatments. Expert Opin Drug Saf 2013;12 (1): 39-51. https://doi.org/10.1517/14740338.2013.740456

5. Gollnick H, Schramm M. Topical drug treatment in acne. Sebaceous gland, acne and related disorders. Dermatol 1998;196:119-25. https://doi.org/10.1159/000017844

6. Sato K, Matsumoto D, lizuka F, et al. Antiandrogenic Therapy Using Oral Spironolactone for Acne Vulgaris in Asians. Aesthet Surg J 2006; 30: 689-94.

https://doi.org/10.1007/s00266-006-0081-0

7. Yamamoto A, Ito M. Topical spironolactone reduces sebum secretion rates in young adults. J Dermatol 1996;23:243-6. https://doi.org/10.1111/j.1346-8138.1996.tb04006.x

8. Corazza M, Strumia R, Lombardi AR, Virgili A. Allergic contact dermatitis from spironolactone. Contact Dermatitis 1996;35: 365-6.

\section{https://doi.org/10.1111/j.1600-0536.1996.tb02421.x}

9. Ilić D, Cvetković M, Blažević-Kamenov N, TasićKostov M. Topical spironolactone in a natural non-ionic emulsifier based vehicle - a safety assessment, Skin and Formulation, 5 ${ }^{\text {th }}$ Symposium $\& 17^{\text {th }}$ Skin Forum, Book of abstracts, 2019.pp.57

10. Tasic-Kostov M, Ilic D, Off-Label Prescriptions in Dermatology: Challenges of New Routes of Administration for Certain Old Drugs, Acta Fac Medicae Naiss 2020; 37(2):131-8

https://doi.org/10.5937/afmnai37-25282

11. Vazquez-Araujo L, Verdu A, Murcia R, et al. Instrumental texture of a typical Spanish confectionery product Xixona Turron as affected by commercial category and manufacturing company. J Texture Stud 2006; 37: 63-79. https://doi.org/10.1111/j.1745-4603.2006.00039.x

12. Rosenthal AJ, Texture profile analysis - how important are the parameters? J Texture Stud 2010;41:672-84.

https://doi.org/10.1111/j.1745-4603.2010.00248.x

13. Lemaitre-Aghazarian V, Piccerele P, Reynier J.P, et al. Textural optimization of water-in-oil emulsions. Pharm Dev Technol 2004; 9: 125-34. https://doi.org/10.1081/PDT-120027424

14. Tadros T. Application of rheology for assessment and prediction of the long-term physical stability of emulsions. Adv Colloid Interface Sci 2004;108109: 227-58.

https://doi.org/10.1016/j.cis.2003.10.025

15. Trapp M. Is there room for improvement in the emollients for adjuvant therapy? J Eur Acad Dermatol Venereol 2007;21: 14-8. https://doi.org/10.1111/j.1468-3083.2007.02382.x 
16. Masmoudi H, Ledreane Y, Piccerelle P. and Kister $\mathrm{J}$. The evaluation of cosmetic and pharmaceutical emulsions aging process using classical techniques and a new method: FTIR. Int J Pharm 2009; 289: 117-31.

https://doi.org/10.1016/j.ijpharm.2004.10.020

17. Wortel VAL, Wiechers JW. Skin sensory performance of individual personal care ingredients and marketed personal care products. Food Qual Prefer 2000; 11: 121-7.

https://doi.org/10.1016/S0950-3293(99)00057-9

18. Rossi GB. and Berglund B. Measurement involving human perception and interpretation. Measurement 2011;44: 815-22.

https://doi.org/10.1016/j.measurement.2011.01.016

19. Seppic, France, Catalog - MontanovTM202, 2001.

20. Lukic M, Jaksic I, Krstonosic V, et al. Effect of small change in oil phase composition on rheological and textural properties of w/o emulsion. JTexture Stud2013; 44: () 34-44. https://doi.org/10.1111/j.1745-4603.2012.00363.x

21. Pund S, Pawar S, Gangurde S, Divate D. Transcutaneous delivery of leflunomide nanoemulgel: mechanistic investigation into physicomechanical characteristics, in vitro antipsoriatic and anti-melanoma activity. Int J Pharm 2015; 487: 148-56

https://doi.org/10.1016/j.ijpharm.2015.04.015

22. Bogdan C, Moldovan LM, Man IM, Crișan M, Preliminary study on the development of an antistretch marks water-in-oil cream: ultrasound assessment, texture analysis, and sensory analysis. ClinCosmetInvestig Dermatol 2016:9 249-55. https://doi.org/10.2147/CCID.S107298

23. Szczesniak AS. Texture is a sensory property. Food Qual Prefer 2002; 13: 215-25. https://doi.org/10.1016/S0950-3293(01)00039-8

24. Zhao Q, Zhao M, Yang B. and Cui C. Effect of xanthan gum on the physical properties and textural characteristics of whipped cream. Food Chem 2009;116: 624-8.

https://doi.org/10.1016/j.foodchem.2009.02.079

25. Yadav NP, Shrivastava $S$, Sinha $P$, et al. Development and evaluation of Aloe vera (L.) Burm. based topical cream formulation. Ann Phytomed 2014;3: 60-5. 


\title{
Dermofarmaceutske emulzije na bazi alkil poliglukozida kao nosači za spironolakton - teksturna analiza
}

\author{
Dušan Ilić, Maja Cvetković, Marija Tasić-Kostov \\ Univerzitet u Nišu, Medicinski fakultet, Katedra Farmacija, Niš, Srbija
}

S A ŽETAK

Acne vulgaris predstavljaju hronično dermatološko oboljenje, koje zahvata pilosebacealnu jedinicu; androgeni igraju važnu ulogu u njihovoj patogenezi. Terapija akni može biti sistemska ili lokalna, koja je uobičajena za lečenje blagih do umerenh oblika akni. Spironolakton (SP) je lek sa antiandrogenim delovanjem i potencijalom za smanjivanje lučenja sebuma; u cilju izbegavanja sistemskih neželjenih efekata, mogao bi se koristiti lokalno u lečenju akni. Danas se sve više pažnje posvećuje teksturnom profilu dermofarmaceutskih emulzija, koji je uglavnom pod uticajem njihove koloidne strukture; analiza teksture se vrši u cilju predviđanja ponašanja emulzionih sistema $u$ realnom vremenu tokom procesa proizvodnje $i$ primene; poslednje navedeno je usko povezano sa obezbeđivanjem adekvatne komplijanse bolesnika i pozitivnim ishodom terapije.

Formulisane emulzije su stabilizovane različitim prirodnim alkil-poliglukozidnim (APG) emulgatorima (cetearil-glukozid i cetearil-alkohol; arahidil-glukozid i arahidil-behenil alkohol), kao nosačima za 5\% SP. Parametri dobijeni analizom teksture bili su čvrstoća i kohezivnost. Studija je pokazala to da je SP uticao na teksturu APG emulzija; različite APG emulzije pokazale su zadovoljavajuće teksturne karakteristike per se i nakon inkorporacije $5 \% \mathrm{SP}$, što bi moglo da ukazuje na njihove zadovoljavajuće aplikativne karakteristike na aknoznoj koži. APG emulgatori mogli bi se koristiti kao stabilizatori emulzionih sistema za topikalni SP. Dermoemulzija sa arahidil-glukozid i arahidil-behenil alkoholom, lipofilnijim emulgatorom, prihvatljiviji je nosač za $5 \%$ SP usled boljeg teksturnog profila

Ključne reči: spironolakton, alkil-poliglukozidni emulgator, teksturni profil, „off-label“ terapija akni 